\title{
Acid rain report assailed as misleading
}

\section{Washington}

A NEW US government report on the causes and effects of acid rain is, depending on who you speak to, either a careful assessment of currrent scientific uncertainty or a misrepresentation of a serious problem. The report is the product of almost seven years of deliberation by scientists working on behalf of the National Acid Rain Precipitation Assessment Program (NAPAP), representing a number of government agencies. Its four volumes are acknowledged even by detractors to contain a comprehensive and mostly sound study of the sources of pollution, atmospheric chemistry, damage to lakes and forests, and potential methods of controlling emissions. But critics, such as Michael Oppenheimer of the Environmental Defense Fund, call the executive summary "skewed" in its summing up of the evidence.

Two particular disagreements stand out. Surveying all of the United States, the report declares that the number of lakes acidified to a damaging degree is no more than a few per cent of the total. NAPAP deems a lake unacceptably acidified only if its $\mathrm{pH}$ is 5.0 or less, when fish die and direct economic loss follows, but according to Jim Gibson of Colorado State University, there is obvious disruption to the food web, with concomitant loss of fish, at a $\mathrm{pH}$ of 6.0 . The NAPAP report also emphasizes that no harm to seedlings has been demonstrated from acidic precipitation at "regional ambient levels", a statement which, says Oppenheimer, is true but misleading; extensive cloud cover of $\mathrm{pH}$ as low as 3.2 has been found in New England and it is these episodes, rather than average immersion at higher $\mathrm{pH}$, that are responsible for forest damage in the north-eastern United States.

Many of those unhappy with the report see too much in it of the beliefs of NAPAP's chairman, J. Laurence Kulp, a geochemist. But Kulp defends the report, saying that the executive summary represents a consensus of the authors of each chapter and of senior scientists from all the participating agencies. He says that lakes naturally exist with a wide range of acidity, and that a $\mathrm{pH}$ of 5.0 is when biological activity falls off most sharply. David Streets, of Argonne National Laboratory, was "entirely comfortable" with the parts of the report to which he contributed. Bob Downing, a spokesman for Kulp's office, did admit that NAPAP had "learned the hard way" the perils of summarizing a hefty report in one-page chapter synopses.

Described by his opponents as "strongwilled", Kulp was apparently given his position at NAPAP for strength of character rather than political leanings. But his panel's report carries undoubted political weight in the dispute between Canada and the United States over the effects of acid rain. Ross Glasgow, First Secretary for the Environment at the Canadian Embassy in Washington, described the NAPAP report as a "very unhelpful" contribution to the acid rain debate, and contrasted it with laudable US action on atmospheric ozone, where the scientific evidence is less clear. But so far there has been no government comment on the NAPAP report, and Glasgow believes that strong criticism of it within the United
States may already have undermined its credibility.

Canadian scientists were given a preview of the report before publication, and made known their worries that by neglecting the higher acidities in Canadian surface waters the magnitude of the problem was not fully expressed. And although, says Glasgow, the NAPAP report was specifically a US study, its omission of evidence from Canada and Europe lent bias to its conclusions.

Kulp himself is about to resign his chairmanship of NAPAP having completed what he regards as a "major milestone". NAPAP, established in 1980 with a ten-year mandate, will continue to compile evidence. A new chairman has not been announced, but both Kulp and Downing expect the programme to carry on in the same vein.

\section{Britain's universities outshone by US fund-raisers? \\ London \\ fund-raisers. According to an official,}

EmbarRAsSED officials at the Department of Education and Science (DES) are trying to play down an off-the-cuff remark by education secretary Kenneth Baker which implied that British universities were not putting in enough effort to raise funds from private sources. Speaking in Chicago during a tour of the United States last week, Baker was reported on BBC radio as saying that more British universities should follow the example set by their US counterparts by employing full-time fund-raising staff. According to the report, Baker said that Southampton was the only British university to do this.

His remarks prompted an immediate and angry response from the universities. The Committee of Vice-chancellors and

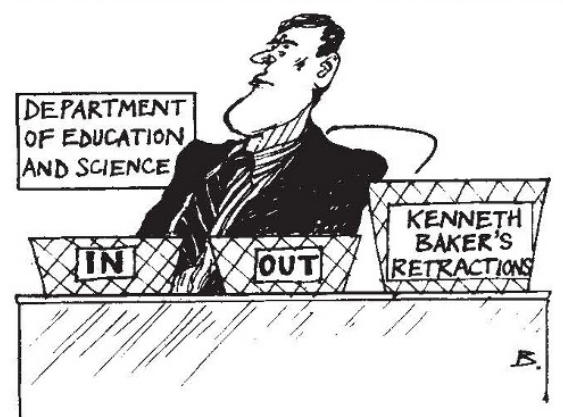

Principals was quick to point out that nearly half of Britain's universities employ fund-raisers, and that universities have doubled their income from outside sources in four years. DES officials - also faced with objections from British school teachers upset at Mr Baker's apparent preference for US teaching methods claim that Baker was inaccurately quoted and that he mentioned not only Southampton but also Oxford as two examples of British universities that have full-time Baker was merely airing his view that fund-raising was "a good thing that ought to be encouraged". The universities are aggrieved because they feel they have responded positively to the harsh economic climate by actively seeking nongovernment support. In 1985-86, Salford University earned nearly a quarter of its total income of $£ 28.9$ million from the open market. A spokesman from Kent University, which is currently seeking a Development Officer to launch a major fund-raising campaign in 1990 , says that Baker's remarks will "reinforce public prejudice that the universities are lying on their backs waiting to be spoon-fed with government money".

Warwick University, which earned 15 per cent of its $£ 37.3$ million income from non-government sources in $1985-86$, points out that it built the largest arts centre outside London with mainly private funds. London University's Imperial College has recently appointed a Director of Public Affairs, with responsibility for fundraising. In general, most British universities do not have a strong tradition of raising funds from alumni, although it is a potential source of funds receiving considerable attention. University fundraisers say that despite Baker's exhortations, funds from private sources will not materialize overnight. Furthermore, it is argued, the government itself could help by introducing more favourable tax incentives for corporate and charitable donations. Perhaps the biggest disappointment over Baker's alleged comments is that the Secretary of State is apparently unaware of the universities' efforts to do as the government has told them.

Simon Hadlington 